\title{
Pre Sowing Seed Treatments of Panchagavya, Magnetic, Electric and Temperature on Growth, Yield, Yield Attributing Traits and Seedling Characters of Tomato (Solanum lycoperscion L.) Variety-Arka Vikas
}

\author{
Venna Vijay Bhaskar Reddy*, Prashant Kumar Rai, E. Krishna Reddy, \\ Sura Venkata Nirmal Hruday and M. Raghavanjaneyulu
} Department of Genetics and Plant Breeding, Naini Agricultural Institute, Sam Higginbottom
University of Agriculture Technology and Sciences, Prayagraj, UP-211007, India

*Corresponding author

\section{A B S T R A C T}

Keywords

Electric, Magnetic, Tomato,

Panchagavya, Hotwater

Article Info

\section{Accepted:}

17 January 2021

Available Online:

10 February 2021
In the present investigation 13 priming treatments including control on tomato seed variety Arka Vikas (selection 22) were used to study under Post Graduate Laboratory and Field Experimentation center during Rabi, 2019-20. Post Graduate Laboratory and Field Experimentation center was laid out in Completely Randomized Design (CRD) and Randomized Block Design (RBD) with four and three replications respectively during Rabi 2019-20.Analysis for the data in laboratory and field experiment revealed significance mean sum of squares due to seed priming treatments for all the characters under study. Maximum germination \%, Root length, Shoot length, shoot length, root length, Seedling length $(\mathrm{cm})$ Seedling fresh weight $(\mathrm{g})$, Seedling dry weight (g),Seedling vigor index-I, Seedling vigor index-II was recorded in $\mathrm{T}_{5}$ - Magnetic field (150mT)for 10Min. Minimum days to flower initiation and minimum days to maturity was recorded in $\mathrm{T}_{5}$. Maximum plant height at 30 DAS $(\mathrm{cm}), 60$ DAS $(\mathrm{cm})$ and 90DAS $(\mathrm{cm})$ and Number of primary branches per plant was recorded in $\mathrm{T}_{5}$. Days to first fruit set was minimum in $T_{5}$. Maximum Number of fruits per plant, fruit weight $(\mathrm{g})$ was recorded in $T_{5}$. Number of seeds per fruit was also maximum in $T_{5^{-}}$ Magneticfield.Seed yield is also high in $\mathrm{T}_{5}$ of Magnetic field and followed by $\mathrm{T}_{8-}$ Electric field $150 \mathrm{~mA}$ for $1 \mathrm{~min}$ followed by $\mathrm{T}_{9}$ Panchagavya $3 \%$ foliar spray for 10 days after transplanting.

\section{Introduction}

Tomato is a rich source of vitamin $\mathrm{A}, \mathrm{C}$ and minerals like $\mathrm{Ca}, \mathrm{P}$ and $\mathrm{Fe}$ (Dhaliwal et al., 2003). It also plays a pivotal role in improving nutrition resource's of poor population as compared to meat, milk, fruits and other high priced fruit items Tomatoes are major contributors of antioxidants such as carotenoids (especially, lycopene and Bcarotene), phenolics, ascorbic acid (vitamin C) and small amounts of vitamin $\mathrm{E}$ in daily diets 
(Rai et al., 2012). Tomato (Solanum lycoperscion) is the most important member of the family Solanaceace. It is native of south America having chromosome number $2 \mathrm{n}=24$. It is an herbaceous annual which sexually propagated by seed. Plants are dicot and grow as a series of branching stem, with terminal bud at the tip. Veins are typically covered with fine short hairs, most plants have compound leaves which are long, odd-pinnate, with 5 to 9 leaflets on petioles. Yellow coloured flowers appearing on the apical meristem have the anthers fused along edges, forming a column surrounding pistil is style. The tomato is classified as berry.

Tomato is commonly called a "poor man's apple". It has a good source of vitamin A and C (Buckseth, 2012). Among the main advantage of application on magnetic field on seeds this method has greater faculty of multiplication with a minimal risk to damage, when compare to manipulating tissue of leaves, roots or stems. One of the main reasons why the seeds treated with magnetic field has spread worldwide lies in positive impact that has on recovery of seed exhibiting a poor quality for certain vegetables species.

\section{Materials and Methods}

The field and lab experiments were conducted during Rabi season 2019-2020. Department of Genetics and plant breeding, Naini Agriculture Institute SHUATS, Prayagraj, (UP).

The statistical designs applied were carried out with Randomized Block Design (RBD) with 13 treatments and 3 replications and Complete Randomized Design (CRD) with 13 treatments and 4 replications. Seed material consists of Tomato variety Arka Vikas. The treatments were represented a To-control, $\mathrm{T}_{1^{-}}$ magnetic field-100Mt for $1 \mathrm{~min} \mathrm{~T}_{2}$-magnetic field-100Mt for $5 \mathrm{~min} \mathrm{~T}_{3}$-magnetic field$100 \mathrm{Mt}$ for $10 \mathrm{~min} \mathrm{~T}_{4}$-magnetic field-150Mt for
1 min $\mathrm{T}_{5}$-magnetic field-150Mt for10min $\mathrm{T}_{6^{-}}$ eletric field- $100 \mathrm{Ma}$ for $1 \mathrm{~min} \mathrm{~T}_{7}$-Eletric field$125 \mathrm{Ma}$ for $1 \mathrm{~min} \mathrm{~T}_{8}$-Eletric field-150 Ma for 1 min $\mathrm{T}_{9}$-Panchagavya-3\% foliar spray -10 $\mathrm{DAT}_{10}$-panchagavya-3\% foliar spray-15DAT $\mathrm{T}_{11}$-hot water treatment $-15^{\circ}{ }^{\mathrm{C}}$ for $10 \mathrm{minT}_{12^{-}}$ Hot water treatment $-30^{0 \mathrm{c}}$ for 15 min.

\section{Electric treatment}

The treatment involves treating seeds with sodium chloride and electric conductivity meter of conducting AC current which includes battery eliminator of 2Amp, Amphi meter of (-ve) and (+ve) charges and rheostat of 1.8amp or $50 \mathrm{ohms}$ current supplier. This involves treating seeds with electric conductivity for certain period of time and followed by air drying. The electric field effects on the transport and metabolism of ions and electrons.

\section{Magnetic treatment}

An electromagnetic field generator "Testron EM-20" with variable static magnetic field (SMF) strength (50 to $500 \mathrm{mT}$ ) with a gap of 5 $\mathrm{cm}$ between pole pieces was fabricated. A D.C. power supply (80V/10A) with continuously variable output current was used for the electromagnet.

A digital gauss meter model DGM-30 operating on the principle of Hall Effect monitored the field strength produced in the pole gap. The probe is made of Indium arsenide crystal and is encapsulated to a nonmagnetic sheet of $5 \mathrm{~mm} \times 4 \mathrm{~mm} \times 1 \mathrm{~mm}$ and could measure 0-2 Tesla with full-scale range in increments of $5 \mathrm{MT}$.

By regulating the current in the coils, desired strength of SMF was monitored, which was measured by a Gauss meter. This involves treating seeds with magnetic field for certain period of time. 


\section{Panchagavya preparation}

Fresh cow dung-5kg, Cow urine-3lit, Cow milk-2lit, Cow curd-2lit, Cow ghee $-1 / 2 \mathrm{~kg}$, Jaggery-500gms/3lit of water, Coconut water3lit, Banana-12, Grape juice -2lit.The contents were stirred by twice a day about $20 \mathrm{~min}$ both in the morning and evening to facilitate aerobic microbial activity. After 15 days of incubation, preparation of Panchagavya solution made into different concentration for treating the seeds.

\section{Results and Discussion}

In different seed priming treatments $\mathrm{T}_{5^{-}}$ Magnetic field $150 \mathrm{mT}$ for 10 minutes has performed the best results when compared to all the other priming treatments and the least results were showed by control. The $\mathrm{T}_{5^{-}}$ Magnetic field-150mT for 10 minutes performed the best results in the field parameters i.e., days to flower initiation (41.66) days to $50 \%$ flowering (47.67), Days to fruit set (56.667), plant height 30DAS $(31.63 \mathrm{~cm})$, plant height 60DAS $(56.63 \mathrm{~cm})$, plant height 90DAS $(76.63 \mathrm{~cm})$, number of branches per plant (18), days to maturity (72.67), number of fruits per plant (21),fruit weight $(46.67 \mathrm{~g})$, number of seed per fruit (176.67), seed yield per plant (15.12g), seed yield per plot (113.4g) and the seed quality parameters i.e., germination percentage (88.50), root length (5.90), shoot length (8.00), seedling length (13.9), seedling fresh weight (6.67), seedling dry weight (5.95), seedling vigour index (12031.5), seedling vigour indexII (840.7).and it was followed by $\mathrm{T}_{8}$-electric field-150 mA @1 min the field parameters i.e., days to flower initiation (42.33), days to $50 \%$ flowering (48.67), Days to fruit set (58.67), plant height 30DAS $(29.83 \mathrm{~cm})$, plant height 60DAS $(54.83 \mathrm{~cm})$, plant height 90DAS $(74.83 \mathrm{~cm})$, number of branches per plant (16.67), days to maturity (84), number of fruits per plant (20.00), fruit weight $(43.67 \mathrm{~g})$, number of seed per fruit (149.33), seed yield per plant $(13.95 \mathrm{~g})$, seed yield per plot $(100.45 \mathrm{~g})$ and the seed quality parameters i.e., germination percentage (82.50), root length (5.80), shoot length (7.85), seedling length (13.65), seedling fresh weight (6.42), seedling dry weight (2.92), seedling vigour index-I (11261.25), seedling vigour index-II (759.0).

It is concluded from the present investigation of seed treatments with different pre-sowing treatments, Magnetic treatment T5- $(150 \mathrm{mT})$ @ (10Min) significantly increased the characters studied in laboratory as well as field experiment. In the different pre-sowing treatments magnetic treatment T5- (150mT) @ (10Min) performed the best results in seedling characters like germination percentage (\%), shoot length, root length, seedling length, fresh weight, dry weight, seedling vigour index I and II and growth and yield characters like days to flower initiation, days to $50 \%$ flowering, plant height, number of primary branches per plant, days to maturity, number of fruits per plant, fruit weight, seed yield and it was followed by T8- electric field (150mA-1min). Thus, application of magnetic field with (150 mT) @ (10Min) may be useful for improving growth, plant height and number of seed per fruit and fruit weight in case of tomato (Table 1 and 2). 
Table.1 Mean performance of seedling characters of tomato

\begin{tabular}{|c|c|c|c|c|c|c|c|c|}
\hline Treatments & Germination\% & $\begin{array}{c}\text { Root } \\
\text { length } \\
\text { (cm) }\end{array}$ & $\begin{array}{c}\text { Shoot } \\
\text { length } \\
\text { (cm) }\end{array}$ & $\begin{array}{c}\text { Seedling } \\
\text { length } \\
\text { (cm) }\end{array}$ & $\begin{array}{c}\text { Fresh } \\
\text { weight } \\
\text { (g) }\end{array}$ & $\begin{array}{c}\text { Dry } \\
\text { weight } \\
\text { (g) }\end{array}$ & $\begin{array}{c}\text { Vigour } \\
\text { index-I }\end{array}$ & $\begin{array}{c}\text { Vigour } \\
\text { Index- } \\
\text { II }\end{array}$ \\
\hline T0 & 74.00 & 4.15 & 5.00 & 9.15 & 2.15 & 2.05 & 6771 & 481.0 \\
\hline T1 & 85.00 & 5.03 & 6.33 & 11.35 & 3.16 & 3.67 & 9647.5 & 569.5 \\
\hline T2 & 86.00 & 5.15 & 7.00 & 12.15 & 4.20 & 4.70 & 10449 & 602.5 \\
\hline T3 & 79.50 & 5.20 & 7.10 & 12.3 & 3.23 & 2.79 & 9778.5 & 628.0 \\
\hline T4 & 87.50 & 5.30 & 7.30 & 12.6 & 2.25 & 3.72 & 11025 & 630.0 \\
\hline T5 & 88.50 & 5.90 & 8.00 & 13.9 & 6.67 & 5.95 & 12031.5 & 840.7 \\
\hline T6 & 78.00 & 5.38 & 7.35 & 12.73 & 4.30 & 4.83 & 9929.4 & 647.4 \\
\hline T7 & 81.50 & 5.45 & 7.50 & 12.95 & 5.33 & 3.83 & 10554.2 & 676.4 \\
\hline T8 & 82.50 & 5.80 & 7.85 & 13.65 & 6.42 & 2.92 & 11261.2 & 759.0 \\
\hline T9 & 79.00 & 4.33 & 6.40 & 10.73 & 4.35 & 4.85 & 8476.7 & 671.5 \\
\hline T10 & 82.00 & 4.70 & 7.15 & 11.85 & 3.25 & 3.76 & 9717 & 623.2 \\
\hline T11 & 81.50 & 4.70 & 6.30 & 11.00 & 4.16 & 3.66 & 8965 & 537.9 \\
\hline T12 & 80.50 & 4.80 & 7.55 & 12.35 & 5.15 & 4.66 & 9941.75 & 531.3 \\
\hline Minimum & 74.0 & 4.15 & 5.00 & 9.15 & 2.15 & 2.65 & 6771 & 481.0 \\
\hline Maximum & 88.50 & 5.90 & 8.00 & 13.90 & 6.67 & 6.95 & 12301.5 & 840.7 \\
\hline GM & 81.96 & 5.07 & 6.99 & 12.05 & 4.196 & 3.994 & 11964.1 & 687.9 \\
\hline S.EM+ & 1.83 & 0.292 & 0.329 & 0.442 & 0.094 & 0.047 & 94.675 & 1.479 \\
\hline CD & 2.59 & 0.835 & 0.943 & 1.262 & 0.267 & 0.136 & 271.842 & 4.264 \\
\hline CV & 5.26 & 11.52 & 9.43 & 7.33 & 14.65 & 12.35 & 16.01 & 10.30 \\
\hline
\end{tabular}


Table.2 Mean performance of growth and yield attributing traits of Tomato

\begin{tabular}{|c|c|c|c|c|c|c|c|c|c|c|c|c|c|}
\hline Treatments & $\begin{array}{l}\text { Pays to flower } \\
\text { Initiation }\end{array}$ & DF50 & $\begin{array}{c}\text { Days to } \\
\text { first } \\
\text { fruit set }\end{array}$ & $\begin{array}{c}\text { PH } \\
(\mathbf{c m}) \text { at } \\
\text { 30 DAS }\end{array}$ & $\begin{array}{c}\text { PH } \\
(\mathrm{cm}) \text { at } 60 \\
\text { DAS }\end{array}$ & $\begin{array}{c}\text { PH } \\
(\mathbf{c m}) \text { at } 90 \\
\text { DAS }\end{array}$ & NBPP & DM & NFPP & $\begin{array}{c}\text { Fruit } \\
\text { weight } \\
\text { (g) }\end{array}$ & $\begin{array}{c}\text { No .of } \\
\text { seeds } \\
\text { per } \\
\text { fruit }\end{array}$ & $\begin{array}{l}\text { Seed } \\
\text { yield } \\
\text { per } \\
\text { plant } \\
\text { (g) }\end{array}$ & $\begin{array}{c}\text { Seed } \\
\text { yield } \\
\text { per } \\
\text { plot } \\
\text { (g) }\end{array}$ \\
\hline T0 & 45.67 & 52.00 & 62.00 & 23.63 & 48.63 & 68.63 & 11.33 & 94.67 & 16.00 & 35.33 & 136.67 & 6.55 & 39.96 \\
\hline T1 & 45.33 & 51.33 & 61.33 & 23.33 & 48.33 & 68.33 & 13.00 & 85.67 & 17.33 & 36.00 & 169.33 & 8.27 & 53.92 \\
\hline T2 & 44.67 & 49.33 & 59.33 & 24.17 & 49.17 & 69.17 & 14.33 & 81.67 & 17.67 & 36.33 & 153.33 & 9.39 & 67.6 \\
\hline T3 & 43.67 & 48.67 & 58.67 & 30.67 & 55.67 & 75.67 & 14.33 & 83.33 & 19.33 & 37.67 & 149.33 & 10.74 & 74.94 \\
\hline T4 & 43.00 & 49.00 & 59.00 & 31.20 & 56.20 & 76.20 & 15.33 & 87.67 & 19.67 & 44.33 & 136.67 & 11.49 & 77.19 \\
\hline T5 & 41.67 & 47.67 & 57.67 & 31.63 & 56.63 & 76.63 & 18.00 & 72.67 & 21.00 & 46.67 & 176.67 & 15.12 & 113.4 \\
\hline T6 & 43.67 & 49.00 & 59.00 & 27.67 & 52.67 & 72.67 & 14.67 & 96 & 19.67 & 38.07 & 160.67 & 9.07 & 58.05 \\
\hline T7 & 42.33 & 48.33 & 58.33 & 27.67 & 52.67 & 72.67 & 16.67 & 84.67 & 19.67 & 39.67 & 160.67 & 12.89 & 82.48 \\
\hline T8 & 42.33 & 48.67 & 58.67 & 29.83 & 54.83 & 74.83 & 16.67 & 84 & 20.00 & 43.67 & 149.33 & 13.95 & $\begin{array}{c}100.4 \\
5\end{array}$ \\
\hline T9 & 43.67 & 50.67 & 60.67 & 24.33 & 49.33 & 69.33 & 14.33 & 94.33 & 17.33 & 40.67 & 166.67 & 10.99 & 69.93 \\
\hline T10 & 43.00 & 50.33 & 60.33 & 29.00 & 54.00 & 74.00 & 12.33 & 86.67 & 16.33 & 36.67 & 163.33 & 9.63 & 61.23 \\
\hline T11 & 43.00 & 50.00 & 60.00 & 28.33 & 53.33 & 73.33 & 14.00 & 94.67 & 19.00 & 31.67 & 142.67 & 7.9 & 49.64 \\
\hline T12 & 43.00 & 50.33 & 60.33 & 29.00 & 54.00 & 74.00 & 13.33 & 86.33 & 17.67 & 35.67 & 152.00 & 8.61 & 53.57 \\
\hline$\underset{\mathbf{m}}{\operatorname{Minimu}}$ & 41.67 & 47.67 & 57.67 & 23.33 & 48.33 & 68.33 & 11.33 & 72.67 & 16.00 & 31.67 & 136.67. & 6.55 & 39.96 \\
\hline$\underset{\mathbf{m}}{\operatorname{Maximu}}$ & 45.67 & 52.00 & 62.00 & 31.63 & 56.63 & 76.63 & 18.00 & 96.00 & 21.00 & 46.67 & 176.67 & 15.12 & 113.4 \\
\hline GM & 43.46 & 49.64 & 59.64 & 27.73 & 52.73 & 72.73 & 14.49 & 87.1 & 18.51 & 38.65 & 156.72 & 10.35 & 69.41 \\
\hline S.Em & 0.49 & 0.79 & 0.79 & 0.9 & 0.9 & 0.9 & 0.74 & 1.63 & 0.86 & 1.91 & 7.74 & 0.13 & 0.84 \\
\hline CD (5\%) & 1.43 & 2.31 & 2.31 & 2.63 & 2.63 & 2.63 & 2.16 & 4.76 & 2.51 & 5.57 & 22.59 & 0.38 & 2.54 \\
\hline $\mathrm{CV}$ & 1.97 & 2.75 & 2.28 & 5.6 & 2.95 & 2.14 & 8.89 & 3.24 & 8.08 & 8.54 & 8.55 & 2.16 & 2.16 \\
\hline
\end{tabular}

\section{References}

AnanthaVashisth, Ravender Singh and D.K. Joshi. (2013) Effect of magnetic field on germination and seedling attributes in tomato (Solanum lycopersicum). Journal of Agricultural Physics, ISSN 0973-032XVol. 13(2): 182-185.

Buckseth, T., Sharma, M.K. and Thakur, K.S. (2012). Genetic diversity and path analysis in tomato (Solanum lycopersicum L.). Vegetable Science 39 (2): 221-223.

Cakmak, T., Dumlupinar, R. and Erdal, S. (2010). Acceleration of germination and early growth of wheat and bean seedlings grown under various magnetic field and osmotic conditions. Bioelectromagnetics. 31: 120-129.
Dhaliwal, M.S., S. Singh and Cheema, D.S. 2003. Line -Tester analysis for yield and processing attributes in Tomato. $J$. Res., 40(1): 49-53.

Girish, Yadav S.K, Lal S.K, Jain S.K., (2011) Static magnetic field treatment enhances seed performance in cotton (Gossypium hirsutum L.). Seed Res., 39 (2): 272-281.

Hozayn M, Animal A.A EL-Mahdy and Abdel-Rahman H.M.H (2015) Effect of magnetic field on germination, seedling growth and cytogenetic of onion (Allium cepa L.) African Journal of African Research. 10 (8): 849-857.

Kumar, R.S. Ganesh, P., Tharmaraj, K., and Saranraj, P. 2011. Growth and development of black gram (Vigna mungo) under foliar application of 
panchagavya as organic source of nutrient. Current Botany, 2 (3): 0911.sciences, 22 (1): 231-232.

Majid, A.S., Latifeh, P. and Nafiseh, A. 2013 Magnetic field effects on seed germination and activities of some enzymes in cumin. Life Sci. J., 10(1): 323- 328.

Mamatha, PK Rai and Saritha Khandka (2019) Comparative Study of Magnetic, Electric and Botanical Seed treatment on Seedling Characters of Desi and Kabuli Chickpea (Cicer arietinum L.) seeds. Int.J.Curr.Microbiol.App.Sci. Vol. 8 (8): 998-1003

Nilimesh Mridha, and Shanti Nagarajan (2014). Effect of Pre-Sowing Static Magnetic Seed Treatment on Germination and Root Characters in Chickpea (Cicer arietinum L.). Journal of Agricultural Physics ISSN 0973-
032XVol. 14, No. 1, pp. 22-29.

Rai, G.K, R. Kumar, A.K. Singh, P. K. Rai, M. Rai, A.K. Chaturvedi and Rai, A.B. 2012. Changes in antioxidant and phytochemical properties of tomato (Lycopersicon esculetum mill) under ambient condition. Pak. J. Bot., 44(2): 667-670.

Srikanth, Prasant Kumar Rai, SarithaKhandka and G.B.N. Jyothi (2018) Influence of Magnetic and Electric field on germination attributes of Chilli (Capsicum annum L.) Seeds Int. J. Pure App. Biosci. 6 (3): 496-501.

Suchitra R, S. Pooonguzhali, B. Saranya, Suguna and K. Jothibasu (2017) Effects of panchagavya on growth and yield of Abelmoschus esculentus ArkaAnamika Int.J.Curr.Microbiol. App.Sci., 6(9): 3090-3097

\section{How to cite this article:}

Venna Vijay Bhaskar Reddy, Prashant Kumar Rai, E. Krishna Reddy, Sura Venkata Nirmal Hruday and Raghavanjaneyulu, M. 2021. Pre Sowing Seed Treatments of Panchagavya, Magnetic, Electric and Temperature on Growth, Yield, Yield Attributing Traits and Seedling Characters of Tomato (Solanum lycoperscion L.) Variety-Arka Vikas. Int.J.Curr.Microbiol.App.Sci. 10 (02): 1993-1998.

doi: https://doi.org/10.20546/ijcmas.2021.1002.239 